\title{
PENERAPAN SISTEM INFORMASI MANAJEMEN UNTUK PENINGKATAN PELAYANAN DI KANTOR DESA BENDO
}

\author{
Prayuga Kurniawan, Putri Ariella Belinda, Septika Puspitasari, Windha Triantika \\ Prayugakurniawan@gmail.com, putriariella7@gmail.com, \\ septikapuspitasari55@gmail.com,wtriantika@gmail.com
}

\begin{abstract}
The Bendo village office uses a management information system to record data on the village community and environment, the village information system makes it easier for the community and other stakeholders to access village data, village development and rural area development. The implementation of government, village programs and budgets is transparent. The accountability for the implementation of government has become more accountable. Indeed, the village information system makes it easier for the community and other stakeholders to access village data, village development and rural area development. This study intends to determine the extent of understanding of the Village Head or Village Apparatus in understanding the implementation of the Village Information System. This research applies This research is a descriptive study using a phenomenological approach. The results of this study found that the implementation of the village information system was not fully optimal. There are still village data that are not fully recorded and have not provided more access to the community to view budgets, work programs and other village policies.
\end{abstract} Keywords: Management Information System, village, village data processing

\begin{abstract}
Abstrak
Kantor desa Bendo menggunakan sistem informasi manajemen untuk mencatat data masyarakat dan lingkungan Desa, sistem informasi desa memudahkan masyarakat dan pemangku kepentingan lainnya untuk mengakses data desa, pembangunan desa dan pembangunan kawasan perdesaan. Pelaksanaan pemerintahan, program dan anggaran desa menjadi transparan. Pertanggungjawaban pelaksanaan pemerintahan pun menjadi lebih akuntabel. Sejatinya, sistem informasi desa memudahkan masyarakat dan pemangku kepentingan lainnya untuk mengakses data desa, pembangunan desa dan pembangunan kawasan perdesaan. Penelitian ini bermaksud untuk mengetahui sejauhmana pemahaman
\end{abstract}


Kepala Desa atau Aparatur Desa dalam memahami mengimplementasi Sistem Informasi Desa. Penelitian ini merupakan penelitian diskriptif dengan menggunakan pendekatan fenomenologis. Hasil penelitian ini menemukan penerapan sistem informasi desa belum sepenuhnya optimal. Masih ada data desa yang tidak terdata secara lengkap serta belum memberi akses lebih kepada masyarakat untuk melihat anggaran, program kerja dan kebijakan desa lainnya.

Kata kunci :Sistem Informasi manajemen,desa, Pengolahan Data desa 


\section{PENDAHULUAN}

\section{A. LATAR BELAKANG}

Desa menjadi pemerintahan terdekat dan terkecil dalam pemerintahan di indonesia. Desa memiliki anggaran yang dialokasikan dari Anggaran Pendapatan Belanja Negara (APBN) yang disebut Dana Desa (DD), Alokasi Dana Desa (ADD) setelah bagi hasil dengan pemerintah kabupaten/kota dan atau provinsi, dan Pendapatan Asli Desa (PADes). Untuk menunjang optimalisasi desa, Pemerintah Pusat dan Pemerintah Daerah berkewajiban melakukan pengembangan Sistem Informasi Desa. Bagi pemerintah daerah, selain berkewajiban melakukan pengembangan Sistem Informasi Desa, juga berkewajiban menyediakan informasi perencanaan pembangunan Kabupaten/Kota untuk Desa. Di dalam Undang-Undang Desa, Pemerintah Desa hanya sebagai pengelola Sistem Informasi Desa itu sendiri. Undang-Undang Desa menjelaskan Sistem Informasi Desa, yaitu meliputi fasilitas perangkat keras dan perangkat lunak, jaringan, serta sumber daya manusia. Secara lebih terinci disebutkan, Sistem Informasi Desa meliputi data desa, data pembangunan desa, kawasan perdesaan, serta informasi lain yang berkaitan dengan pembangunan desa dan pembangunan kawasan perdesaan. Secara lebih lengkap tentang Sistem Informasi Desa dijelaskan pada Pasal 86, Bagian Ketiga Tentang Sistem Informasi Pembangunan Desa dan Pembangunan Kawasan Perdesaan. Dalam Undang-Undang Desa disebutkan:

1) Desa berhak mendapatkan akses informasi melalui sistem informasi Desa yang dikembangkan oleh Pemerintah Daerah Kabupaten/Kota.

2) Pemerintah dan Pemerintah Daerah wajib mengembangkan Sistem Informasi Desa dan pembangunan Kawasan Perdesaan.

3) Sistem Informasi Desa meliputi fasilitas perangkat keras dan perangkat lunak, jaringan, serta sumber daya manusia.

4) Sistem informasi Desa meliputi data Desa, data Pembangunan Desa, Kawasan Perdesaan, serta informasi lain yang berkaitan dengan Pembangunan Desa dan pembangunan Kawasan Perdesaan.

5) Sistem informasi Desa dikelola oleh Pemerintah Desa dan dapat diakses oleh masyarakat Desa dan semua pemangku kepentingan.

6) Pemerintah Daerah Kabupaten/Kota menyediakan informasi perencanaan pembangunan Kabupaten/Kota untuk Desa. 
Di era modern, Sistem Informasi Desa sudah harus berbasis teknologi (mesin tik, komputer, telepon, faksimili, printer dan jaringan internet) dan Sumber Daya Manusia (SDM). Teknologi dan SDM tidak bisa dipisahkan. tidak ada SDM yang bisa mengoperasikannya, tentu akan mubazir. Begitupun sebaliknya, ada SDM yang berkualitas, namun teknologinya tidak tersedia, juga tidak bisa menghadirkan Sistem Informasi Desa yang ideal.

\section{LANDASAN TEORI}

\section{A. SISTEM}

Sistem berasal dari bahasa Latin (systēma) dan bahasa Yunani (sustēma). Pengertian sistem secara bahasa adalah adalah suatu kesatuan yang terdiri atas komponen atau elemen yang dihubungkan bersama untuk memudahkan aliran informasi, materi, atau energi untuk mencapai suatu tujuan. Menurut Kamus Besar Bahasa Indonesia (KBBI), sistem adalah perangkat unsur yang secara teratur saling berkaitan sehingga membentuk suatu totalitas. Sistem juga diartikan sebagai susunan yang teratur dari pandangan, teori, asas, dan sebagainya. KBBI juga mendefinisikan pengertian sistem sebagai sebuah metode. Pengertian Sistem Sebuah sistem terdiri dari atas bagian-bagian yang bergabung untuk suatu tujuan tertentu. Sebuah sistem bisa terdiri dari bagian-bagian yang saling berkaitan yang beroperasi Bersama untuk mencapai sasaran, maksud atau tujuan tertentu. Definisi sistem menurut Jogiyanto H.M dalam bukunya Analisis dan Disain menyebutkan bahwa: "sistem adalah Kumpulan elemen-elemen yang berinteraksi untuk mencapai suatu tujuan tertentu. (Jogiyanto H.M. 2010).

\section{Karakteristik sistem}

\section{Komponen Sistem}

Suatu sistem terdiri atas sejumlah komponen yang saling berhubungan, yang berarti saling berkerjasama untuk membentuk satu kesatuan. Pada komponen sistem tersebut terdiri atas komponen berupa bagian-bagian dari sistem atau subsistem.

\section{Batasan system}

Batasan sistem termasuk daerah yang membatasi antara suatu sistem dengan sistem lainnya atau dengan lingkungan luarnya. Batasan pada sistem tersebut memungkinkan suatu sistem itu dipandang sebagai suatu kesatuan. 


\section{Lingkungan luar system}

Lingkungan luar sistem yaitu diuar batas dari sistem yang telah mempengaruhi operasi sistem tersebut. Lingkungan bisa saja bersifat menguntungkan yang harus tetap dijaga dan yang tidak menguntungkan mesti dijaga dan dikendalikan, kalau tak akan mengganggu kelangsungan hidup dari sistem tersebut.

\section{Penghubung system}

Penghubung sistem adalah media penghubung antara satu subsistem dengan subsistem yang lainnya. Lewat penghubung tersebut maka dapat memungkinkan sumber-sumber daya akan mengalir dari subsistem kepada subsistem yang lainnya.

\section{Masukan}

Input atau masukan adalah segala sesuatu yang masuk ke dalam sistem dan selanjutnya menjadi bahan yang diproses. Masukan dapat berupa hal-hal yang berwujud (tampak secara fisik) maupun yang tidak tampak.

\section{Keluaran}

Keluaran (output) merupakan hasil dari pemrosesan. Keluaran sistem merupakan hasil dari energi yang diolah dan diklasifikasikan menjadi output yang bermanfaat dan sisa pembuangan. Pada sistem informasi, keluaran bisa berupa suatu informasi, saran, cetakan laporan, dan sebagainya.

\section{Pengolah system}

Suatu sistem menjadi suatu bagian pengolah yang akan mengubah masukan menjadi keluaran. Sistem produksi akan mengolah bahan baku tersebut menjadi bahan jadi.

\section{Sasaran system}

Suatu sistem pasti tujuan atau sasaran berupa objek. Sasaran dari sistem tersebut sangat menentukan masukan atau input yang dibutuhkan oleh sistem dan keluaran yang akan dihasilkan oleh sistem.

\section{B. INFORMASI}

Pengertian Informasi adalah sekumpulan data atau fakta yang telah diproses dan diolah sedemikian rupa sehingga menghasilkan sesuatu yang bisa dipahami dan memberikan manfaat bagi penerimanya. Data dan fakta adalah "bahan baku" informasi, tetapi tidak semuanya bisa diolah menjadi informasi.(Sidharta Lani 1995) "Sebuah system informasi adalah sistem buatan manusia yang berisi himpunan terintegrasi dari komponen-komponen 
manual dan komponen-komponen terkomputerisasi yang bertujuan untuk mengumpulkan data, memproses data, dan menghasilkan informasi untuk pemakai.

\section{Manfaat Informasi}

- Meminimalkan risiko Anda mengambil keputusan yang salah.

- Memberikan gambaran yang tepat dan faktual sesuai dengan kondisi yang ada saat ini.

- Menyajikan tren atau kecenderungan tentang suatu hal di masa mendatang.

- Mengurangi potensi keresahan akibat kondisi yang tidak pasti.

- Menjadi dasar dalam menentukan solusi dari sebuah permasalahan.

- Mengefektifkan alur kerja dalam sebuah organisasi.

- Mempertahankan citra positif perusahaan dan meningkatkan kepercayaan.

- Membantu menyusun materi promosi agar lebih jelas dan terarah.

- Menjadi dasar pertanggungjawaban atas sebuah keputusan atau tindakan yang sudah dilakukan.

- Memberikan bukti valid (bukan kesan, opini, atau isu) kepada pihak lain.

\section{MANAJEMEN}

manajemen adalah suatu proses di mana seseorang dapat mengatur segala sesuatu yang dikerjakan oleh individu atau kelompok. Manajemen perlu dilakukan guna mencapai tujuan atau target dari individu ataupun kelompok tersebut secara kooperatif menggunakan sumber daya yang tersedia. Selain itu, manajemen juga dapat diartikan menurut etimologinya. Manajemen berarti sebagai seni mengatur dan melaksanakan, berdasarkan Bahasa Prancis kuno. Manajemen juga dapat diartikan sebagai usaha perencanaan, koordinasi, serta pengaturan sumber daya yang ada demi mencapai tujuan secara efektif dan efisien.Dengan menerapkan ilmu manajemen, diharapkan sesuatu yang sedang dikerjakan dapat selesai tepat waktu dan tanpa ada hal yang menjadi sia-sia. Tujuan tercapai karena terorganisir secara baik. 


\section{D.SISTEM INFORMASI MANAJEMEN}

Sistem Informasi Manajemen adalah seperangkat prosedur gabungan yang mengumpulkan dan menghasilkan data yang andal, relevan, dan terorganisir dengan baik yang mendukung proses pengambilan keputusan suatu organisasi. Singkatnya, ini adalah sekelompok proses di mana data diperoleh, dianalisa, dan ditampilkan dengan cara yang berguna untuk tujuan pengambilan keputusan.Sistem ini adalah alat yang sangat berguna untuk tujuan meninjau dan mengendalikan operasi perusahaan. Tujuan utama dari sistem ini adalah untuk mengatur semua data yang dikumpulkan dari setiap tingkat perusahaan, meringkasnya, dan menyajikannya dengan cara yang memfasilitasi dan meningkatkan kualitas keputusan yang diambil untuk meningkatkan profitabilitas dan produktivitas perusahaan.Sistem ini biasanya berbasis komputer termasuk lembar excel sederhana atau platform yang lebih kompleks. Informasi yang dikumpulkan dan dianaliasa dalam sistem biasanya berasal dari sumber internal dan eksternal. Menurut (Hanif Al Fatta, 2007:10) berpendapat sistem informasi yang terdiri dari komponenkomponen di atas disebut dengan istilah blok bangunan (building block), yaitu blok masukan (input block),blok model (model block), blok keluaran (output block), blok teknologi (technology block), dan blok kendali (control block). Sebagai suatu sistem, keenam blok tersebut masing masing saling berinteraksi satu dengan yang lainnya membentuk satu kesatuan untuk mencapai sasarannya.

manfaat utama dari penggunaan sistem informasi manajemen yang efektif:

- Manajemen dapat memperoleh gambaran umum dari seluruh operasi mereka.

- Manajer memiliki kemampuan untuk mendapatkan umpan balik tentang kinerja mereka.

- Organisasi dapat memaksimalkan manfaat dari investasi mereka dengan melihat apa yang berfungsi dan apa yang tidak.

- Manajer dapat membandingkan hasil dengan kinerja yang direncanakan dengan mengidentifikasi kekuatan dan kelemahan dalam rencana dan kinerja.

- Perusahaan dapat mendorong peningkatan alur kerja yang menghasilkan penyelarasan proses bisnis yang lebih baik dengan kebutuhan pelanggan.

- Banyak keputusan bisnis dipindahkan dari manajemen atas ke level organisasi yang lebih efisien, dengan pengetahuan dan pengalaman yang mumpuni. 


\section{ARTI PENTING PENGEMBANGAN SISTEM}

(Prabowo 2015) Pengembangan sistem (systems development) merupakan menyusun suatu sistem yang baru untuk menggantikan sistem yang lama secara keseluruhan atau memperbaikis istem yang telah ada. Sistem yang lama perlu diperbaiki atau diganti disebabkan karena beberapa hal, yaitu sebagai berikut ini:

1. Adanya permasalahan-permasalahan (problems) yang timbul di sistem yang lama.

2. Ketidakberesan dalam sistem yang lama menyebabkan sistem yang lama tidak dapat beroperasi sesuai dengan yang diharapkan.

3. Kecurangan-kecurangan disengaja yang menyebabkan tidak amannya harta kekayaan perusahaan dan kebenaran dari data menjadi kurang terjamin.

4. Kesalahan-kesalahan yang tidak disengaja yang juga dapat menyebabkan kebenaran dari data kurang terjamin.

5. Tidak efisiennya operasi.

6. Tidak ditaatinya kebijaksanaan manajemen yang telah ditetapkan

Efektivitas merupakan salah satu dimensi dari produktivitas hasil yang mengarah pada keberhasilan kerja yang maksimal, yang mencapai target secara kuantitas, kualitas dan waktu. (Pasolong 2007). Keberhasilan suatu organisasi yang harus bisa mepmertimbangkan antara sasaran organisasi dan mekanisme mempertahankan dalam mengejar sasaran dua hal tersebut harus bisa diimbangi, penilaian dari efektivitas harus berkaitan dengan masalah sasaran dan tujuan yang direncanakan (Georgopolous dan Tannenbaum 1985). Seperti halnya pemerintah sebagai penyelenggara kebijakan publik harus dapat memberikan kinerja yang baik untuk masyarakatnya, misalnya pelayanan publik. Pemerintah sebagai penyelenggara pelayanan publik harus dapat memberikan pelayanan yang cepat dan tepat agar masyarakat merasakan kepuasan dalam menerima pelayanan publik yang diberikan oleh pemerintah (Lukman 2000)

Banyak permasalahan yang terjadi pada negara ini seperti pelayanan publik yang kurang memadai dan tidak cepat dan tepat, banyak faktor yang menyebabkan pelayanan publik dinegara ini tidak berjalan sesuai dengan apa yang diinginkan, seperti infrastruktur yang tidak memadai dan pemerintah selaku penyelenggara pelayanan publik tidak serius dalam melaksanakan pelayanan publik. (Pramusinto \& Kumorotomo, ; 2009). 


\section{E. Birokrasi Desa}

Dinamika perkembangan demokrasi ternyata tidak sederhana dibayangkan. Kedaulatan rakyat pada asas desa kendati telah dibingkai dalam konstruksi perundangan yang seragam, dalam praktinya memiliki beragam corak. Agenda kekuasaan yang berasal dari negara pada prinsipnya hendak dikembangkan dengan menekankan peran sentralisasi kekuasaan negara melalui kelembagaan desa. Birokrasi desa masih lebih fokus pada urusan pemerintahan dan politik domestik dari pada berfikir untuk memodernisasi menejemen birokrasinya secara profesional. Oleh karena itu, birokrasi desa kerap kali menjadi faktor penghambat proses akselerasi modernisasi desa, sebab setiap hal-hal atau kebijakan-kebijakan pemerintah tingkat atasnya yang masuk ke desa, selalu difilter terlebih dahulu kemudian disesuaikan dengan kepentingan politik atau kepentingan pribadi. Dalam kondisi ini, posisi birokrasi tidak lebih sebagai bentuk inefisensi organisasi.

\section{i. Pengertian Pelayanan}

Menurut Moenir Pelayanan adalah kegiatan yang dilakukan oleh seseorang atau sekelompok orang dengan landasan faktor materi melalui sistem, prosedur dan metode tertentu dalam rangka usaha memenuhi kepentingan orang lain sesuai dengan haknya. Pelayanan hakikatnya adalah serangkaian kegiatan, karena itu pelayanan merupakan sebuah proses. Sebagai proses, pelayanan berlangsung secara rutin dan berkesinambungan, meliputi seluruh kehidupan orang dalam masyarakat dalam interaksi langsung antar seseorang dengan orang lain atau mesin secara fisik, dan menyediakan kepuasan pelanggan. (Moenir 2006)

\section{ii. Bentuk-Bentuk Pelayanan}

Penyelenggaraan pelayanan yang sesusai dengan bentuk dan sifatnya, menurut Keputusan Mentri Negara Pendayagunaan Apa ratur Negara Nomor 63 Tahun 2003 (Undang-undang Republik Indonesia 2009) tentang pedoman umum penyelenggaraan pelayanan publik terdapat empat pola pelayanan, yaitu:

1. Pola pelayanan fungsional, yaitu pola pelayan publik diberikan oleh penyelenggaraan pelayanan sesuai dengan tugas, fungsi dan kewenagannya.

2. Pola pelayanan terpusat, yaitu pola pelayanan yang diberikan secara tunggal 
oleh penyelenggara pelayanan terkait lainnya yang bersangkutan.

3. Pola pelayanan terpadu yang dibagi kedalam dua bagian pola pelayanan yaitu:

a. Pola Pelayanan Terpadu Satu Atap

Pola pelayanan terpadu satu atap diselenggarakan dalam satu tempat yang meliputi berbagai jenis pelayanan yang tidak mempunyai keterkaitan proses dan dilayani melalui beberapa pintu. Terhadap jenis pelayanan yang sudah dekat dengan masyarakat tidak perlu disatu atapkan.

b. Pola Pelayanan Terpadu Satu Pintu

Pola pelayanan terpadu satu pintu diselenggarakan pada satu tempat yang memiliki keterkaiatan proses dan dilayani melaluisatu pintu.

c. Pola Pelayanan Gugus Tugas

Yaitu petugas pelayanan publik secara perorangan atau dalam bentuk gugus tugas ditempatkan pada instansi pemberi pelayanan dan lokasi pemberi pelayanandan lokasi pemberi pelayanan tertentu.

\section{iii. Faktor Yang Mempengaruhi Pelayanan}

Pelayanan yang baik pada akhirnya akan mampu memberikan kepuasan kepada masyarakat. Pelayanan yang optimaal pada akhirnya juga akan mampu meningkatkan image organisasi sehingga citra organisasi di mata masyarakat terus meningkat. Adanya citra organisasi yang baik, maka segala yang dilakukan oleh organisasi akan dianggap baik pula.(Nugraha arif ahaditya zulfi 2015)

Faktor utama yang mempengaruhi pelayanan adalah sumber daya manusia. Artinya peranan manusia (karyawan) yang melayani masyarakat merupakan faktor utama karena hanya dengan manusialah pelanggan dapat berkomunikasi secara langsung dan terbuka.

Menurut Atep Adya Barata (2003: 37), "Kualitas pelayanan terbagi menjadi dua bagian yaitu kualitas pelayanan internal dan eksternal". Masing-masing bagian tersebut dipengaruhi oleh beberapa faktor yang cukup penting, yaitu sebagai berikut:

- Faktor yang mempengaruhi kualitas pelayanan internal (interaksi pegawai 
organisasi), yaitu pola manajemen umum organisasi, penyediaan fasilitas pendukung, pengembangan sumber daya manusia, iklim kerja dan keselarasan hubungan kerja, serta pola insentif.

- Faktor yang mempengaruhi kualitas pelayanan eksternal (pelanggan eksternal), yaitu pola layanan dan tata cara penyediaan layanan, pola layanan distribusi jasa, pola layanan penjualan jasa, dan pola layanan dalam penyampaian jasa.(Barata 2003) 


\section{METODE PENELITIAN}

Penelitian ini menggunakan pendekatan kualitatif deskriptif yaitu penguraian tentang fenomena dan kejadian-kejadian pada saat sekarang, jenis penelitian ini memberikan gambaran tentang segala bentuk fenomena di lapangan bertujuan untuk memperoleh informasi-informasi tentang keadaan saat ini. Peneliti ini tidak menguji hipotesa, melainkan hanya mendeskripsikan informasi apa adanya sesuai dengan variabel-variabel yang diteliti

Penelitian ini mengkaji penerapan system infomasi manajemen di kantor Desa Bendo. Dengan demikian, penelitian ini hanya mengkaji satu variabel atau variabel tunggal yaitu penerapan system informasi manajemen untuk pelayanan masyarakat di Desa bendo

Penelitian ini merupakan penelitian deskriptif dimana penulis memberikan gambaran tentang upaya pemerintah desa Bendo dalam mengembangkan system pelayanan masyarakat dengan menggunakan system informasi manajemen modern . Informan dalam penelitian ini adalah beberapa pejabat terkait di Desa Bendo yang dipandang dapat memberikan informasi berkenaan dengan masalah yang diteliti. Teknik Pengumpulan Data dilakukandengan cara:

a) Observasi yang digunakan sebagai teknik pertama dilakukan untuk mengamati secara langsung di lapangan yaitu penerapan system informasi manajemen dalam pelayanan publik

b) Dokumentasi, cara pengumpulan data dengan cara membaca, mempelajari, mengutip, dan merangkum data yang berkaitan dengan masalah yang diteliti.

c) Wawancara yaituPengumpulan data yang dilakukan dengan cara tanya jawab dengan pihak yang dianggap kompeten dengan masalah yang diteliti.

Analisis Data yang digunakan dalam penelitian ini yaitu mengunakan analisis deskriptif dengan menggambarkan kenyataan atau keadaan-keadaan atas suatu objek dalam bentuk uraian kalimat berdasarkan keterangan-keterangan dari pihak-pihak yang berhubungan langsung dengan penelitian ini 


\section{PEMBAHASAN}

\section{A. Perangkat Keras Sistem Informasi Desa}

Undang-Undang tentang Desa menjelaskan Sistem Informasi Desa meliputi fasilitas perangkat keras dan perangkat lunak, jaringan, serta sumber daya manusia. Secara lebih terinci disebutkan, Sistem Informasi Desa meliputi data desa, data pembangunan desa, kawasan perdesaan, serta informasi lain yang berkaitan dengan pembangunan desa dan pembangunan kawasan perdesaan.

Salah satu implementasi Sistem Informasi Desa adalah desa memiliki perangkat teknologi untuk mempermudah dan mempercepat penyelenggaraan pemerintahan desa. Hal mendasar yang harus dimiliki desa, terkait teknologi adalah mesin tik dan komputer. Dua komponen ini sangat vital untuk melaksanakan roda pemerintahan desa dan pelayanan kepada masyarakat. Mesin tik dan komputer digunakan untuk mencatat administrasi pemerintahan desa dan membuat surat- surat yang diperlukan masyarakat. Hasil penelitian, Desa Bendo hanya memiliki mesin tik sebanyak 1 unit. Dan sayangnya mesin tik nya tidak berfungsi secara optimal. Hal ini dikarenakan mesin tik sudah jarang dipakai dan tidak terawat lagi.

Teknologi mesin tik memang terasa jadul alias jaman dulu sekali. Tidak heran, jika desa terlihat mengabaikan teknologi yang lahir pada Abad ke-18 ini dan menggantinya dengan komputer, teknologi yang makin canggih dan cepat untuk digunakan dalam menjalankan pemerintahan desa dan pelayanan masyarakat.

Desa bisa saja mengabaikan mesin tik, dengan alasan kemajuan zaman. Sebagai penggantinya adalah computer. Dari hasil penelitian ini, desa Bendo memiliki 5 unit computer dan dapat kelimanya berfungsi secara optimal. Untuk sumber daya manusia (SDM) nya masih beberapa yang dapat menggunakan computer dengan maksimal dan sisanya kemampuan dalam mengoperasikan computer masih perlu ditingkatkan.

\section{B. Kepemilikan Data Desa dan Tempat Penyimpanannya}

Selain perangkat teknologi (mesin tik dan computer), pemerintah desa juga berkewajiban memiliki data desa. Data desa merupakan dokumen sangat penting 
tentang desa. Meliputi sejarah, batas-batas teritorial, jumlah penduduk, tingkat pendidikan penduduk, mata pencaharian dan lain sebagainya. Termasuk juga, jika ada data tentang kekayaan desa, badan usaha milik desa (BUMDesa) dan potensipotensi kekayaan desa.

Dari hasil penelitian, penyimpanan data-data penting Desa Bendo di buku besar sudah berakhir pada tahun 2012-2013 lalu, dan mulai 2014 data-data desa sudah disimpan dalam bentuk file di computer. Hal ini dilakukan untuk mempermudah dalam pengajuan dan pelaksanaan program-program desa.

\section{Kepemilikan data pembangunan desa dan penyimpanannya}

Selain data desa, pemerintahan desa juga semestinya memiliki data pembangunan desa dan kawasan perdesaan. Data pembangunan desa merupakan data tentang pembangunan di wilayah desa itu sendiri untuk kemakmuran dan kesejahteraan masyarakat desa. Dengan data pembangunan desa, pembangunan di desa, baik infrastruktur maupun SDM desa dan masyarakat desa, menjadi terukur sehingga pembangunan bisa dilakukan secara berkesinambungan. Berdasarkan penelitian, data-data pembangunan desa di simpan dalam bentuk file di computer dan dokumen tersebut dicetak ketika diperlukan seperti contoh untuk setoran laporan ke kecamatan.

\section{Pemanfaatan internet dan kepemilikan website desa resmi}

Ada satu faktor lagi yang bisa menunjang penyelenggaraan pemerintahan desa bisa berjalan dengan baik, yaitu internet. Pemanfaatan internet secara maksimal berpotensi besar menjadikan tata kelola pemerintahan desa berjalan transparan dan akuntabel. Transparan artinya masyarakat desa dan semua pemangku kepentingan bisa mengakses penyelenggaraan pemerintah desa dan pengelolaan anggaran dengan mudah, terang benderang dan tidak ditutup-tutupi. Dengan begitu, penyelenggara pemerintahan desa menjadi sungguh-sungguh memberikan pertanggungjawaban atas penyelenggaraan pemerintahan, program kerja dan penggunaan anggaran, baik secara hukum dan moril. Berdasarkan penelitian, Desa Bendo berlangganan internet untuk menunjang penyelenggaraan pemerintah desa. Seperti penggunaan aplikasi siskeudes untuk mengelola seluruh sumber dana yang ada di APBDesa dan menghasilkan laporan per masing-masing sumber dana. Selain itu Desa Bendo pernah memiliki website desa resmi yaitu http://bendo.tulungagungdaring.id . 
namun situs itu sekarang telah ditangguhkan dikarenakan masa hosting telah habis dan tidak diaktifkan kembali. Hal ini disebabkan pengetahuan aparatur desa mengenai internet masih perlu di tingkatkan sehingga mereka masih kurang memperdulikan pentingnya memiliki website desa resmi. Padahal selain berfungsi sebagai sumber informasi desa, website desa juga dapat menjadi portal berita serta sarana promosi potensi desa

\section{E. Transparansi Data Pembangunan Desa dan Penyebaran Informasi Data Pembangunan Desa}

Dalam konteks transparasi, Desa Bendo memberikan akses kepada masyarakat dan pemangku kepentingan untuk mengetahui data pembangunan desa. Dalam memberikan akses kepada masyarakat, desa melakukannya masih dengan cara sosialisasi, baliho, dan musyawarah. Desa masih belum memanfaatkan teknologi internet untuk menyampaikan informasi data pembangunan desa. Hal ini dikarenakan desa menyesuaikan dengan tingkat kemampuan masyarakat desa mengenai teknologi informasi berbasis internet.

\section{F. Pelayanan Di kantor Desa Bendo}

Kualitas pelayanan public merupakan salah satu agenda reformasi birokrasi pemerntahn yang bertitik tolak dari kenyataan buruk kondisi factual kualitas pelayanan public yang sebagian besar ditentukan oleh kualitas sikap dan karakter aparatur pemerintah yang terpuji, korup, dan tidak bertanggungjawab, sehingga membuat masyarakat tidak puas akan pelayanan yang diberikan oleh aparat.

Peningkatan kualitas pelayanan public merupakan salah satu isu yang sangat penting untuk aparat-aparat dipemerintahan yang juga berada di kantor desa. Dalam hal ini terjadi karena disatu sisi tuntutan masyarakat terhadap kualitas pelayanan juga semakin besar dan semakin banyak sementara praktek penyelenggaraan pelayanan tidak mengalami perubahan yang berarti. Masyarakat yang setiap waktu menuntut pelayanan public yang berkualitas, meskipun tuntutan tersebut sering tidak sesuai dengan harapan karena pelayanan public yang terjadi selama ini masih berbelit-belit, mahal, dan melelahkan.

Seiring dengan berjalannya kebijakan otonomi daerah, aparat birokrasi pemerintahan di daerah dapat mengelola dan menyelenggarakan pelayanan public 
yang lebih peduli dengan kebutuhan masyarakat daerahnya. Terhadap konsep yang mendasar dalam hal mengelola urusan yang mengatur pemerintahan local ini yakni adanya prakarsa sendiri berdasarkan pada aspirasi masyarakat setempat demi mencapai kesejahteraan mereka. Namun pada kenyataan penyelenggaraan pelayanan public yang dilakukan oleh pemerintah masih dihadapkan pada pelayanan yang belum efektif dan efisien serta kualitas sumber daya manusia yang belum memadai. Hal ini terlihat dari masih banyaknya pengaduan dari masyarakat yang menuntut peningkatan kualitas pelayanan public.

Pelayanan public merupakan tanggung jawab pemerintah dan dilaksanakan oleh instansi pemerintahan, baik itu pusat maupun daerah. Pelayanan public berbentuk pelayanan barang public maupun pelayanan jasa, oleh sebab itu substansi administrasi sangat berperan dalam mengatur dan mengarahkan seluruh kegiatan organisasi pelayanan dalam mencapai tujuan.

Contoh keluhan yang sering terjadi dan terdengan dari masyarakat yang berhubungan dengan aparatur pemerintah adalah selain berbelit-belit akibat birokrasi yang kaku, perilaku oknum aparatur yang kadang kala kurang bbersahabat, juga kinerja pegawai dalam memberikan pelayanan dalam hal ini ketepatan waktu dalam memberikan pelayanan, kualitas yang masih sangat rendah untuk masyarakat.

Realibility (kehandalan) merupakan kemampuan kantor desa untuk menyediakan pelayanan yang terpercaya, konsisten dan kesesuaian pelayanan. Hal ini penting mengingat masyarakat membuktikan pembuktian janji-janji pelayanan di kantor Desa Bendo Kecamatan Gondang Kabupaten Tulungagung. Kehandalan ini dapat kita ukur dari kecermatan petugas melayani, adanya standar pelayanan yang jelas, kemahiran petugas pelayanan dalam mnggunakan alat bantu dalam proses pelayanan. Masalah pelayanan yang diterapkan di kantor Desa Bendo biasanya dirapatkan dengan aparat-aparat desa, namun penyampaian-penyampaian yang masih kurang jelas kepada masyarakat inilah yang menyebabkan standar pelayanan yang masih kurang jelas, dan bagaimana kemampuan petugas dalam menggunakan alat bantu pelayanan (computer).

Persyaratan kehandalan yang merupakan unsur pelayanan yang baik, masih belum dipenuhi oleh kantor Desa Bendo, hal ini dapat kita ketahui dari masih adanya keluhan masyarakat tentang kesalahan pengetikan pada dokumen resmi mereka, sebagian besar petugas pelayanan yang kurang mahir menggunakan computer, dan tidak disiplin waktu dalam memberikan pelayanan. 
Unsure kehandalan berikutnya yaitu ketepatan waktu. Berdasarkan hasil pengamatan dan wawancara, pegawai kantor desa Bendo kurang disiplin waktu untuk hadir di kantor tepat waktu . masih terdapat beberapa pegawai yang datang pukul 08.00 bahkan pukul 09.00 pagi. Dimana hal ini tidak sesuai dengan jam kerja yang sudah ditentukan. Selain itu banyak warga yang merasa kecewa karena kehadiran pegawai yang tidak tepat waktu mempengaruhi kedisiplinan pelayanan yang tidak tepat waktu juga. Pengamtan penulis selama 7 kali melakukan observasi di kantor desa Bendo, penulis melihat bahwa hanya ada 2 orang yang hadir dikantor tepat waktu yaitu kepala desa dan juga operator desa. Hasil penelitian menunjukkan bahwa persyaratan kehandalan yang merupakan unsure pelayanan yang baik, masih belum dipenuhi oleh pelayanan di kantor desa Bendo. Hal ini dapat kita ketahui dari masih adanya keluhan masyarakat tentang kesalahan pengetikan pada dokumen resmi mereka, sebagian besar petugas pelayanan yang kurang mahit menggunakan computer, dan tidak disiplin waktu dalam memberikan pelayanan.

Responsive(ketanggapan) merupakan kesanggupan untuk membantu dan menyediakan pelayanan secara cepat dan tepat, serta tanggap terhadap keinginan konsumen serta mendengarkan dan mengatsi keluhan yang diajukan konsumen. Ketanggapan merupakan salah satu syarat dari pelayanan yang baik, tolak ukur ketanggapan dalam proses pelayanan yaitu pelayanan yang merespon setiap pelanggan/pemohon yang ingin mendapatkan pelayanan, petugas melakukan pelayanan yang cermat, dengan waktu yang tepat semua keluhan pelanggan direspon oleh petugas.

Berdasarkan hasil penelitian diperoleh keterangan bahwa ketanggapan petugas dalam pelayanan di kantor desa Bendomasih kurang memuaskan, masyarakat masih mengeluh soal sikap petugas yang lambat dan terkadang sikapnya kurang menyenangkan hati.

Empaty (empati) setiap pemberian pelayanan harus memiliki rasa empati kepada masyarakat, sikap pemberi layanan yang menunjukkan rasa peduli yang besar kepada kebutuhan penerima layanan, dengan begitu pemberi layanan akan melayani pelanggan dengan sepenuh hati, sebelumnya telah di ketahui bahwa pegawai di antor desa Bendo tidak sedikit yang datang terlmbat, akibatnya pelayanan terlambat dibuka dan waktu pelayanan terasa sangat singkat, sebab masyarakat yang mengajukan pelayanan juga jumlahnya tidak sedikit, akhirnya yang ada bebrapa masyarakat yang tidak dilayani. 
Selain itu, salah satu warga desa Bendo menjelaskan bahwa ada perlakukan diskriminatif dalam pelayanan di kantor desa Bendo. Dimana orang-orang terdekat dari para pegawai kantor akan dilayani dengan cepat atau didahulukan dari yang lain. Berdasarkan situasi tersebut, tentu saja unsure empati belum dimiliki oleh para petugas di kantor Desa Bendo.

\section{. KESIMPULAN DAN SARAN}

\section{Kesimpulan}

Berdasarkan hasil penelitian dan pembahasan pada bab sebelumnya maka dapat ditarik kesimpulan sebagai berikut: Penerapan system infomasi manajemen di Desa Bendo masih belum sepenuhnya siap untuk membantu peningkatan kinerja pelayanan desa. Teknologi informasi modern masih belum sepenuhnya terealiasikan secara menyeluruh. Perlengkapan dan peralatan yang dibutuhkan masih terbatas dan sumber daya manusia yang masih perlu dikembangkan .

\section{Saran}

1. Pihak Desa harus lebih memperhatikan kebutuhan yang diperlukan untuk peningkatan kinerja pegawainya baik dari segi infrastruktur maupun kemampuan pegawainya agar pelayanan bisa lebih cepat,mudah dan efisien

2. Warga desa harus lebih berinisiatif dalam memberikan saran dan kritikan terkait kinerja apparat desa.

3. Masyarakat desa harus memiliki partisipasi yang tinggi dalam penyelenggaraan programprogam yang ada di desa agar tujuan penyelenggaraan program-program tersebut dapat tercapai. Sebaiknya program-program desa juga selaras dengan program-program di pemerintahan pusat sehingga berbagai ragam kebijakan program serta implementasinya akan semakin menguatkan posisi saing desa.

4. Disarankan kepada kepala Desa, untuk lebih proaktif dalam mengawasi kinerja pegawai di kantor desa dalam menjalankan tugasnya. Agar pegawai yang bekerja di kantor desa 
Bendo lebih meningkatkan kualitas dalam bekerja yang bertujuan untuk memberikan pelayanan terbaik sesuai dengan harapan masyarakat.

5. Meningkatkan kinerja aparatur pemerintah desa agar mencapai kinerja yang optimal dengan cara pelatihanpembekalan dan pengenalan serta pemahaman tugas pokok dan fungsi sehingga seluruh aparatur nantinya dapat melaksanakan fungsinya secara professional demi mendukung jalannya pemerintahan dan pembangunan di desa Bendo. Salah satu pertimbangan pentingnya pelatihan ini adalah pemerintah desa sebagai jajaran terdepan dalam proses penyelenggaraan pemerintahan perlu memahami secara tepat tentang dinamika kehidupan masyarakat di desa Bendo.

6. Fungsi-fungsi dalam pemerintahan desa perlu untuk dimaksimalkan agar bias sejalan dengan tujuan tata kelola desa.

7. Tata kelola yang baik di desa harus dilakukan secara terstruktur dan sistematis agar desa bukan hanya bias mempertanggungjawabkan seluruh kegiatan yang dilakukan tetapi juga bias meningkatkan daya saing desa.

8. Lebih mengoptimalkan penggunaan system informasi desa melalui aplikasi berbasis web dimana hal tersebut memiliki manfaat seperti:

- Menjadikan kantor desa leboh efektif

- Kantor desa menjadi lebih efisien

- Pemerintah desa menjadi lebih transparan

- Menjadikan layanan public lebih baik

- Lebih akuntable

- Warga lebih aktif berpartisipasi dalam proses pembangunan desa

- Warga memperoleh akses informasi desa lebih baik

\section{DAFTAR PUSTAKA}

Barata, Atep Adya. 2003. Dasar-Dasar Pelayanan Prima. Elex Media Komputindo.

Jogiyanto H.M. 2010. Analisa Dan Desain Sistem Informasi. Yogyakarta: Andi.

Lukman, Sampara. 2000. “Manajemen Kualitas Pelayanan.” Jakarta: STIA Lan Press.

Moenir, Drs.H.A.S. 2006. "Manajemen Pelayanan Umum Di Indonesia.” 
Nugraha arif ahaditya zulfi. 2015. “Analisis Kepuasan Masyarakat Terhadap Pelayanan Publik Berdasarkan Indeks Kepuasan Masyarakat." Universitas Negeri Yogyakarta 151: 10-17. https://doi.org/10.1145/3132847.3132886.

Prabowo, Rachmad Gesah Mukti. 2015. "Pengembangan Sistem."

Sidharta Lani. 1995. Sistem Informasi Bisnis Pengantar Sistem Informasi Bisnis. Sistem Informasi Bisnis.

Undang-undang Republik Indonesia. 2009. "Undang Undang Nomor 25 Tahun 2009 Tentang Pelayanan Publik." Udang-Undang Nomor 25 Tahun 2009 Tentang Playanan Publik. 